\title{
The Determinant Factors of Inbound Tourists to Bali
}

\author{
Hariyadi $^{1}$ \\ Ministry of National Development Planning/BAPPENAS
}

\begin{abstract}
This research intends to determine whether Bali Tourism has economic spillover effects on sub national area. The authors investigate those externalities through inbound and domestic tourism flows model by Yang and Wong (2012). In addition, other issue related to production factors migration (Capello, 2016) also covered in this paper. The result shows that air transportation plays a very important role in the inflow of tourism. Consequently, central and regional governments need to strengthen cooperation with the private sector in order to build and improve accessibility and domestic connectivity. Dealing with migration motive, it needs to increase local businesses participation in the national tourism industry.
\end{abstract}

Keywords: Tourism, agriculture, effect, Bali 


\title{
The Determinant Factors of Inbound Tourists to Bali
}

\author{
Hariyadi, BAPPENAS
}

\section{Introduction}

Bali, small island with an area of $5,636.66 \mathrm{~km} 2$ is the icon of Indonesia tourism. A Province in which 4,200,100 people living and running economy has been transform for half of a century from agricultural sector into the service sector. In 2013, accommodation, eating and drinking had the largest share (19.5 percent) while agriculture, forestry, and fisheries only 15.2 percent. In 2015, agricultural land in Bali reached 353.802 hectares consists of 80.063 hectares of wetland and 273.739 hectares of land instead of rice fields. Nonagricultural land occupied only about 209.864 hectares. Recently, the difference between land use of agriculture (62.8 percent) and non-agricultural (37.2 percent) is key evidence that tourism play important role in upcoming Bali economy.

The previous regime had set numbers of major programs in collaboration with key stakeholders including government ministries and the private sector in development of Masterplan for Acceleration and Expansion of Indonesia Economic Development (MP3EI) ${ }^{2}$ to accelerate and expand of economic development in Indonesia. It involved 22 main economic activities that designated based on the inherent potential and strategic value of each of them. One of those is tourism. In addition, there are six economic corridors, which are identified as growth centers and expected to boost economic development throughout the nation. First, Sumatra Economic Corridor as a center for production and processing of natural resources and the nation's energy reserves. Second, Java Economic Corridor as a driver for national industry and service provision. Third, Kalimantan Economic Corridor has function as energy reserves. Fourth, Sulawesi Economic Corridor as a center for production and processing of national agricultural, plantation, fishery, and oil and gas. Fifth, Bali - Nusa Tenggara Economic Corridor as a gateway for tourism and national food support. Papua -Maluku Islands Economic Corridor as a center for the development of food, fishery, energy, and national mining. This policy already appointed Bali-Nusa Tenggara as the center of tourism in Indonesia.

Discussion on tourism or any economic activities always related to spillover effect issues. Not only positive externalities, but also negative externalities would be derived from those activities. This mechanism also applies to tourism flow. For instance, development of sector tourism in Bali will provide benefits of tourism sector in neighboring areas. As central government dedicated Bali-Nusa Tenggara as a tourism center, it is expected to generate economy generate tourism economy among the region as increase of the supply side will increase demand of goods and service as well as interregional labor movement among region.

Bali experienced a fluctuating economic growth. Indonesia Central Bureau of Statistics (BPS) data showed the number of unstable but still in the range of 6-7 percent. Bali economic growth in 2011 reached 6.66 percent. A year later, the growth rate had reached 6.96 percent. However, it is finally dropped in 2015 by 6.04 percent. Despite of its fluctuation, the growth is still above the national growth rate as showed by 4.67 percent growth in the same year. Tourism sector become more central in Bali economy. In 2011, the share of trade, hotel, and restaurant that related to tourism sector reached 30.62 percent. It increased by 0.61 percent compared to year 2010. In contrast, the agriculture sector decreased from 18.14 percent to 17.34 percent.

This phenomenon has raised many questions for authors, one of which is whether a significant increase in the tourism sector growth is a product of tourism flow. Thus, this paper will investigate how the relationship of tourism flow in Bali with the potential factors together contributing to spillover effects in this research. In addition, it will analyze what determinant

2 Masterplan for Acceleration and Expansion of Indonesia Economic Development (MP3EI) is an integral part of the national development planning scheme based on Development Plan 2005-2025 (Law No. 17 year 2007) and the Medium-Term Development Plans (Presidential Decree No. 7 year 2009) 
factor that people move to Bali. Popular motive of resident movement between regions is to find better job. At this point, the author needs to observe the relationships between individual characteristics and dependent variable that can describe labor migration from the neighbor circumstance area to Bali. In brief, the purposes of the study are to examine the factors in tourism flow that resulted in spillover effects and to identify pattern of people movement to detect labor migration.

\section{Literature Review}

Role of the city and the region continues to grow in tourism planning and development policies (OECD, 2015). Tourism channels such as visitor quantity, tourism variety, seasonality patterns, revenues and benefit have a broad impact in the economy. Incera (2005) also stated that trade within the scope of the national will change the contribution of other trade activities at the regional GDP. For instance, an increase in direct consumption or supply the needs of intermediate goods industry in the area. Therefore, tourism is very likely to trigger more trading activity.

Deloitte (2008) stated tourism activities create spillover effect on the other sector such as retail, manufacturing, health, and life sciences. It also has wider contribution to the social-economic policy agenda including economic and social inclusion, enterprise/business formation, sustainable and development impact, and regeneration impact.

To measure contribution of tourism on economy, there are three measurement used. First, direct industry, associated with visitor spending and tourism associated with the government. Second, related to the tourism economy of private and government investment. It also explains the domestic supply chain industry for direct input. Third, the number of workers in the industrial sector as well as the purchasing supply chain in retail, leisure and entertainment is described as total contribution.

One of studies to measure spillover effect in inbound and domestic tourism flow (Yang and Wong, 2012) confirmed the existence of spillover effects in both inbound and domestic tourism flows, and suggested main factors are physical infrastructure and tourist attractions. In addition, it has been observed that although the degree of openness to inbound tourists is important for inbound tourism flows, a city's income is vital to enhance domestic tourism flows. Significant differences in spillover effects and determinants of tourism flows are also discovered among cities in different regions.

Yang and Wong (2012) said that in the tourism, spillover effect can occur when a tourism activity in a particular region provides direct or indirect effect to tourism activities in the other region. The effects can be either a positive impact of activity development or spatial interaction among tourist destinations. Refers to the image below, it can be showed that the spillover effect constructed by supply and demand components. From the supply side point of views, there are several factors dealing with spillover productivity such as market access spillover, joint promotion, and negative events. On the other hand, the demand side is depicted multi-destination tourism and travel.

Figure 1. Factors contributing to spillover effects in tourism flows

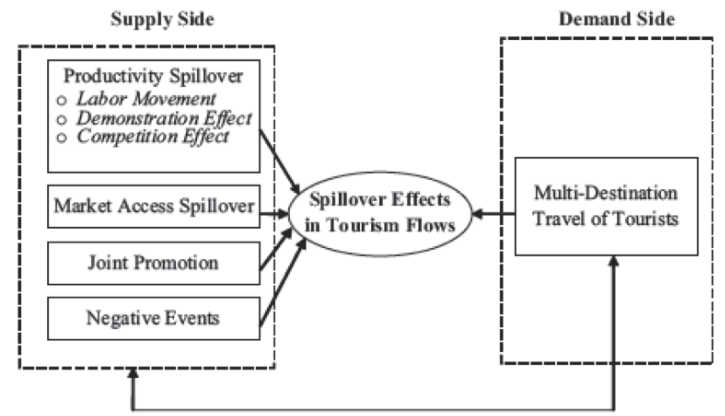


Furthermore, Yang and Wong (2016) explains that productivity spillover occurs when productivity gap or technicality exist between local firms and foreign firms. These applied from high-level destinations to low-level destinations. Generally, there are three things related to spillover productivity. First, the labor movement, it illustrates that highly productivity depend on knowledge and ability. Second, the demonstration effect, a picture of the increased of profitability and efficiency because low-productivity firms adopt the corporate framework from established region. Lastly, the competition effect, it encourages companies to make innovation in order to increase productivity and able to compete in the market.

Following that, Yang and Wong (2016) described that market access spillover shows conditions when a region which has a high market share causes other regions able to access the market easily. They also explained that joint promotion is a collaboration conducted by tourism organizations to achieve the potential visitors by combining tourist attractions. Tourists with multidestination travel plans described by previous discussion (Smith, 1983). It related to the behavior patterns of long-haul tourists for a stopover and visit several tourist destinations in order to increase the utility and value added.

In labor migration perspective, there are several motives on worker's migration such as intergenerational factors as well as welfare improvement and career opportunities. In intergenerational perspective, the remuneration is one factor on the two-sector model that attract the production factors to migrate (Capello, 2016). Therefore, increasing demand of good leads to price went up and encourage interregional reallocation of production resources. As a result, that effect will influence the marginal product of the factors value.

\section{Methodology}

To estimate the tourism flow relationships, this study adjusts Yang and Wong (2012) model respect to data constraint. However, the author eliminate the time series factor and only focus on cross section data. There are several factors included on the model. The dependent variable is $\mathrm{Ti}$ represent the number of inbound or tourist arrivals to region $\mathrm{i}$. The first independent variable included is hoteli. It implies the number of hotels in municipality i. This variable for measuring tourism infrastructure capacity. Then, in this paper, the authors will include investi to reflect the trade openness degree.

In this model, the author use regional budgets for tourism and cultural functions as a proxy of investment. Then, the density of roads in municipality $i$ is represented by roadi also used as predictor. It calculated by dividing the total length of roads with area on those cities. Still related to infrastructure, the author is involving variable aeroi as number of plans arrival in municipality i. Another variable are GDPi that quantifies the gross domestic product (GDP) of municipality $i$ and telei as line capacity quantity in municipality i. Furthermore, variables that represent tourism sector that included on the model are the number of national parks (NP), the number of World Heritage Sites (HERI), and AAAA (A4) as variable indicates the overall attractiveness of the destination. Those variables describe attractiveness of destination place.

In this paper, the author only limits Bali as a destination. Then, NTB and NTT as the neighbor areas associated with Bali. Thus, an estimation model can be developed to examine the relationship between variables as follows:

$$
\begin{aligned}
\ln T_{i}=\beta_{0}+\delta \sum_{j=1}^{N} & w_{i j} \ln T_{j}+\beta_{1} \ln \text { hotel }_{i}+\beta_{2} \ln \text { invest }_{i} \\
& \quad+\beta_{3} \ln \text { road }_{i}+\beta_{4} \ln \text { aero }_{i}+\beta_{5} \ln \text { GDP }_{i}+\beta_{6} \ln \text { tele }_{i}+\beta_{7} \ln N P_{i}+\beta_{8} \ln H E R I_{i}+\beta_{9} \ln A 4_{i} \\
& +\beta_{10} \text { D03 }_{i}+\varepsilon_{i}
\end{aligned}
$$

In the model, the author also includes dummy variable D03it that reflects event related to government policy on central tourism development. In addition, the spatial connection between municipality $i$ and $j$ is reflected by wij used as the element of the spatial weighting matrix W. At least, $\varepsilon_{i t}$ is assumed as white noise where mean zero and limited variance. Regression is expected to estimate spillover effects $(\delta)$, the significance of that estimation can be evaluated from particular statistical tests on $\delta$, such as the asymptotic $t$ statistic. It 
measures the magnitude of spillover effects in tourism flows. In order to obtained the number, the author adopt Yang and Wong (2016) construction by develop the matrix W $\left(\mathrm{w}_{\mathrm{ij}}\right)$. The matrix describes the relationship between region $i$ and $j$. The cell is assigned to be 1 if region $j$ is one of the two nearest neighbors of region $i$, and 0 otherwise.

In terms of second objective, the authors will perform descriptive analysis and inferences. One form of descriptive analysis through the two-way tabulation explain the link between variables. Tabulation also be used to see how the pattern of data distribution. The inference can be constructed to see the relationship between the dependent and independent variables in a linear model. In order to analyze which factors that influence people move to Bali, tourism destination data as dependent variable (Bali) is considered. When the data transformed to be a categorical data, it can be assumed that people are travelling on two location which is Bali $\left(\right.$ Bali $\left._{i}=1\right)$ and Non Bali $\left(\right.$ Bali $\left._{i}=0\right)$.

Furthermore, there are several predictors involved in the model. First, the main purpose of the last travel $\left(\right.$ Objective $\left._{\mathrm{i}}\right)$. This variable explain reason why people travelling to Bali such as:

1) Vacation/recreation,

2) Professional/Business,

3) Mission/meeting/congress,

4) Education/training and others.

The authors apply Edu $\mathrm{E}_{\mathrm{i}}$ that categorize level education of people to accomplish this variable. Another predictor used is Capita, which is variable as proxy for wage. Capita can explain why people travel to Bali. Consumption and employment are the reasons behind the assumption. Someone with a large income would aim to spend some money on the tourism sector. Conversely, a person with low income will move to Bali to increase their income. The

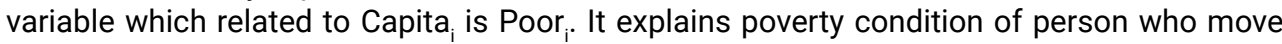
to Bali.

Moreover, the author include spatial factor on this model. As previously known that the area around contribute to the establishment of the New Economic Geographic, particularly related to the migrant worker. Therefore, the authors assumed that the variable place of origin in this case NTB and NTT , would affect the movement of people heading to Bali. Finally, to complete those variables, the authors include variables that associated to employment issues such as unemployment status condition (Uemp $)_{\mathrm{i}}$ ), employment status condition $\left(\mathrm{Emp}_{\mathrm{i}}\right)$, and job seeking status (Jseek).

Because of dependent variable is assumed as binary outcome, alternative models that can be developed is probit models. Binary data analysis can be used two types of regression analysis is logit and probit. The author chooses probit because it more simple than logit. The probit simulation done by considering the sample selection model. Basically the probit is a simulation of a normal multivariate with a full correlation structure. Basic probit regression is a dichotomising process of continuous normal variables to see the effect of predictor variables. In this model, the $X \beta$ value is the assumption of $z$ value of normal distribution. The interpretation of the estimation can be interpreted that for each change of one unit in $X_{i}$ eat there is a change of $\beta_{i}$ in the $z$ value of the dependent variable. The econometric tools will be the widely used statistical programs Stata.

$$
\begin{aligned}
\text { Bali }_{i}=\text { Constant } & +\beta_{1} \text { Objective }_{1 i}+\beta_{2} \text { Edu }_{i}+\beta_{3} \text { Capita }_{i}+\beta_{4} \text { Poor }_{i}+\beta_{5} N T B_{i}+\beta_{6} N T T_{i}+\beta_{7} \text { Uemp }_{i} \\
& +\beta_{8} \text { Emp }_{i}+\beta_{9} \text { Jeek }_{i}+e_{i}
\end{aligned}
$$

\section{Data}

\subsection{Description of the Dataset}

Province in Figures, annual publication is powerful resource to obtain some information i.e. geography, climate, government, population and employment, social, agriculture, industry, trade, transport and communications, tourism, price and finance, consumption patterns and GRDP. It is also exhibited regional comparison among regions in province or national scale. This publication presents the primary data from the results of BPS activities as well as 
secondary data collected from various government and private agencies. For this purpose, the authors employ data in 2012 from Bali, Nusa Tenggara Barat, and Nusa Tenggara Timur province.

The research also utilizes information from the Indonesia Social and Economic Survey (Susenas) 2014. Susenas was first conducted in 1963 to collect data of household consumption expenditure. To obtain data more accurately, Susenas household consumption expenditure carried out on a quarterly basis since 2011. It includes 300,000 households distributed in all provinces in Indonesia. Moreover, data consumption expenditure collected in 2014 Susenas divided into 2 (two) groups, namely food and non-food consumption.

The advantage of this sample is data enumeration results can be presented both national and provincial levels. Then, the cumulative results of the implementation of the record during the four quarters presented to the district or city level. Several indicators have been identified related to assumptions on the literature review i.e. frequency of travelling, the main purpose of the last travel, destination of travelling, the origin place, education, and employment status to analyze and satisfy objective.

\subsection{Descriptive Data}

Descriptive statistics of dependent and explanatory variable in spillover econometrics model performed in table 1 in which 35 observations applied for each variable except Inroad and Inaero that have observation less than 35. It implies that several municipalities do not have airport. For instance, Bali only has airport which located in Badung area. Moreover, the high deviation showed from Inpdrb_h which represents Gross Domestic Regional Product (GDRP). It is an evidence that the gross value created by all economic activities related to hotels and tourism in a region over a certain period varies greatly among municipalities.

Then, related to number of tourist, data showed the variation in the number of tourists between regions is quite large. Both Intourist and w_tourist have standard deviation of 2.1 and 2.7, respectively. Another interesting point clearly seen from the number of attraction place. Standard deviations greater than 10 show that each region still prioritizes quantity compared to quality. For example, in NTT almost all districts are promoting more than 10 attraction place. However, the number of tourist visited is not significant. In contrast, although the number of attraction place is fewer but tourists visiting Bali and NTB are very large.

Table 1. Descriptive statistics of dependent and explanatory variable

\begin{tabular}{|c|c|c|c|c|c|}
\hline Variable & $\mathrm{Obs}$ & Mean & Std. Dev. & Min & $\operatorname{Max}$ \\
\hline Intourist & 35 & 10.91325 & 2.117325 & 6.50279 & 15.3204 \\
\hline w tourist & 35 & 10.71532 & 2.774723 & 0 & 14.41956 \\
\hline lnhotel & 34 & 3.519026 & 1.358533 & 1.386294 & 6.385194 \\
\hline $\operatorname{lnfdi}$ & 35 & 22.19631 & .8195316 & 19.81006 & 24.4267 \\
\hline Inroad & 29 & -.3686486 & .9078156 & -2.388867 & 1.63413 \\
\hline Inaero & 18 & 7.035874 & 1.461098 & 4.510859 & 10.94519 \\
\hline lnpdrb_h & 35 & 19.43068 & 4.336424 & 2.818995 & 22.5964 \\
\hline Inphone & 33 & 8.395226 & 1.261123 & 6.073044 & 11.36758 \\
\hline$n p$ & 35 & .2571429 & .4434396 & 0 & 1 \\
\hline heri & 35 & .2571429 & .4434396 & 0 & 1 \\
\hline a 4 & 35 & 16.88571 & 10.32066 & 1 & 36 \\
\hline d03 & 35 & .2571429 & .4434396 & 0 & 1 \\
\hline
\end{tabular}


Table 2. Descriptive statistics of dependent and explanatory variable

\begin{tabular}{|c|c|c|c|c|c|}
\hline Variable & Obs & Mean & Std. Dev. & Min & Max \\
\hline bali & $1,098,280$ & .0035592 & .0595528 & 0 & 1 \\
\hline objective & 105,972 & 5.306034 & 2.6076 & 1 & 9 \\
\hline edu & 920,918 & 4.237551 & 3.798198 & 1 & 14 \\
\hline kapita & $1,098,280$ & 749661.6 & 802634.3 & 75664.88 & $7.87 e+07$ \\
\hline poor & $1,098,280$ & .074125 & .2619743 & 0 & 1 \\
\hline$n+b$ & $1,098,280$ & .0200996 & .1403411 & 0 & 1 \\
\hline ntt & $1,098,280$ & .0437721 & .2045877 & 0 & 1 \\
\hline uemp & $1,098,280$ & .33314 & .4713363 & 0 & 1 \\
\hline emp & $1,098,280$ & .4786621 & .4995447 & 0 & 1 \\
\hline jseek & $1,098,280$ & .0218724 & .1462669 & 0 & 1 \\
\hline
\end{tabular}

Source: Susenas, 2014

Turning to Table 2, it shows that the respective number of observations for all variables mostly are as much as $1,098,280$. Only Objective and Education less than that number i.e. 105,972 and 920,918 , respectively. The categorical data Bali had an average of 0.0035592 and a standard deviation of 0.0595528 . The variation of move2 was high, meaning that there has been a small increase in movement objective. It is because each person has different motive to go to Bali. It is noticeable that the minimum value of 1 and a maximum value of 9 . Furthermore, the average Capita is $749,661.6$ with standard deviation $802,634.3$. The value of deviation was very high, it is implies that the different wage among individual is too high. The rest variables are categorical data, it reflected from minimum data is 0 and maximum data is 1 . However, the mean and deviation are varies because each variable has different total observation.

Table 3. Tabulation people move to Bali $($ Bali=1)

\begin{tabular}{|r|rrr|}
\hline bali & Freq. & Percent & Cum. \\
\hline 0 & $1,094,371$ & 99.64 & 99.64 \\
1 & 3,909 & 0.36 & 100.00 \\
\hline Total & $1,098,280$ & 100.00 & \\
\hline
\end{tabular}

\section{Result}

\subsection{Spillover Econometrics}

Since Ordinary Least Squares produce the best, linear, unbiased, and efficient (BLUE) estimators as proved by the Gauss-Markov Theorem, the authors examine the regression with the dependent variable Intourist with 11 independent variables in the first stage. OLS regression was run and the following results were obtained. Table shows that $R^{2}$ is 0.9855 means 98.55 percent variation of Intourist is explained by variation of predictor. However, the joint test for all parameter shows F-statistics $=18.42$ is greater than $F_{4,24,0.05}=243$ which indicates that fail to reject $\mathrm{H}_{0}$, meaning that at least one estimate is not significant. Probability (F-statistic), gives the significance level at which we are not able to reject the hypothesis that the set of right-hand side variables has no predictive value. Hence, the endogenous variable (Intourist) is not explained by the fitted model. 
In order to attain the fitted model, the authors examine stepwise regression with probability 0.05 and 0.10 , respectively. The output shows that Stepwise $(\mathrm{pr}=.05)$ and $(\mathrm{pr}=.10)$ provide $\mathrm{R}^{2}$ larger than 70 percent, it means that more than 70 percent variation of Intourist is explained by variation of independent variable. The joint test for all parameter shows that F-statistics for all model are statistically significant in any level of alpha. It indicates that the $\mathrm{H}_{0}$ is rejected, meaning that at least one estimate is significant in both model. In addition, from table summary above, it can be seen that one or two of t-statistics from particular model are statistically significant for any level of alpha. It means that rejecting the null hypothesis or $\beta$ is not zero. Hence, data provide evidence that on model Stepwise 1 , Inaero is relevant for predicting Intourist. In Stepwise 2, w_tourist and Inaero are relevant for that purpose.

Table 4. OLS and stepwise regression estimation

\begin{tabular}{|c|c|c|c|}
\hline Lntourist & OLS & $\begin{array}{c}\text { Stepwise, } \\
\operatorname{pr}(.05)\end{array}$ & $\begin{array}{c}\text { Stepwise, } \\
\operatorname{pr}(.1)\end{array}$ \\
\hline w_tourist & $\begin{array}{c}1.019228 \\
(.4759065)\end{array}$ & & $\begin{array}{l}.01750783^{*} \\
(.0892965)\end{array}$ \\
\hline Lnhotel & $\begin{array}{c}-3.632268 \\
(2.291763)\end{array}$ & & \\
\hline Lnfdi & $\begin{array}{c}.6493906 \\
(.6988487)\end{array}$ & & \\
\hline Lnroad & $\begin{array}{c}3.602128 \\
(1.778067)\end{array}$ & & \\
\hline Lnaero & $\begin{array}{l}1.792495 \\
(.69193)\end{array}$ & $\begin{array}{c}1.069371^{\star \star \star} \\
(.180909)\end{array}$ & $\begin{array}{l}.9309953^{\star \star \star} \\
(.1760273)\end{array}$ \\
\hline Lnpdrb_h & $\begin{array}{l}-1.681739 \\
(.8588225)\end{array}$ & & \\
\hline Lnphone & $\begin{array}{c}.4010637 \\
(3.341352)\end{array}$ & & \\
\hline $\mathrm{Np}$ & $\begin{array}{c}7.676198 \\
(3.341352)\end{array}$ & & \\
\hline Heri & $\begin{array}{c}-11.64988 \\
(5.36224)\end{array}$ & & \\
\hline $\mathrm{a} 4$ & $\begin{array}{c}-.129912 \\
(.0628345)\end{array}$ & & \\
\hline d03 & $\begin{array}{c}11.4622 \\
(7.562429)\end{array}$ & & \\
\hline Constant & $\begin{array}{c}19.72117 \\
(16.46898)\end{array}$ & $\begin{array}{l}2.501163^{\star} \\
(1.296131)\end{array}$ & $\begin{array}{c}1.906913 \\
(1.194442)\end{array}$ \\
\hline Observation & 13 & 13 & 13 \\
\hline R-Squared & 0.9855 & 0.7606 & 0.8720 \\
\hline R-Squared (adjusted) & 0.8246 & 0.7388 & 0.7925 \\
\hline F-statistic & 6.19 & 34.94 & 23.91 \\
\hline Prob > F & 0.3045 & 0.0001 & 0.0002 \\
\hline
\end{tabular}

Refer to Yang and Wong (2012), given that the air flight provides a high accessibility to inbound visitors and rich domestic travelers, it is beneficial for inbound and domestic tourism development. The airport tends to bring large number of transit tourists. Hence, $\beta 4$ is expected to be positive. A major concern of the results is the spillover coefficient $\delta$. In Stepwise 2 model, $\delta$ is 0.018 . This result suggests that if inbound tourist arrivals to the nearest-neighboring municipalities (NTB and NTT) of a particular municipality (Bali) increase by 1 percent, inbound tourist arrivals to that municipality will increase by 0.018 percent through the cross municipality spillover effects. 


\subsection{Two Way Tabulate People Migration}

Obviously, $26,029,770$ of the total population in Indonesia, or more than 10 percent of them travel from their home region, while the remaining 226,006,059 (89.67 percent) do not travel outside the region. Furthermore, approximately 958.417 (3.68 percent) of the population chose to travel to Bali. The remaining 25,071,353 (96.32 percent) traveled to areas other than Bali.

If observations made by age group, the productive age group 15-65 has the greatest proportion of traveling to Bali. In addition, 75 percent of people who go to Bali come from the age group 15-65 years. The table also shows that as many as 23.6 percent are under 15 years age group, while the remaining 2.47 percent are age group 65 years and over.

Education and traveling table show 30.65 percent of people with elementary school education have the greatest percentage on travelling followed by group who earn high education. Figures on the table show there are as many as 18.87 percent of people who incorporated into that category. Furthermore, there are 15.54 percent of the group of junioreducated people and the equivalent has more than one traveling frequency. The vocational group is 8.64 percent and followed by the Bachelor group with a proportion of 5.87 percent.

Table 5. Tabulation of people movement with Bali as destination

\begin{tabular}{|c|c|c|c|}
\hline bali & $\begin{array}{l}\mathrm{mo} \\
0\end{array}$ & 1 & Total \\
\hline 0 & $\begin{array}{r}226006059 \\
90.01 \\
100.00 \\
89.67\end{array}$ & $\begin{array}{r}25071353 \\
9.99 \\
96.32 \\
9.95\end{array}$ & $\begin{array}{r}251077412 \\
100.00 \\
99.62 \\
99.62\end{array}$ \\
\hline 1 & $\begin{array}{r}0 \\
0.00 \\
0.00 \\
0.00\end{array}$ & $\begin{array}{r}958417 \\
100.00 \\
3.68 \\
0.38\end{array}$ & $\begin{array}{r}958417 \\
100.00 \\
0.38 \\
0.38\end{array}$ \\
\hline Total & $\begin{array}{r}226006059 \\
89.67 \\
100.00 \\
89.67\end{array}$ & $\begin{array}{r}26029770 \\
10.33 \\
100.00 \\
10.33\end{array}$ & $\begin{array}{r}252035829 \\
100.00 \\
100.00 \\
100.00\end{array}$ \\
\hline
\end{tabular}

Source: Susenas, 2014

Table 6. Tabulation of people movement with Bali as destination based on age category

\begin{tabular}{|c|c|c|c|}
\hline \multirow[b]{2}{*}{ agecat } & \multicolumn{2}{|c|}{ bali } & \multirow[b]{2}{*}{ Total } \\
\hline & 0 & 1 & \\
\hline \multirow[t]{4}{*}{0} & 72260261 & 226231 & 72486492 \\
\hline & 99.69 & 0.31 & 100.00 \\
\hline & 28.78 & 23.60 & 28.76 \\
\hline & 28.67 & 0.09 & 28.76 \\
\hline \multirow[t]{4}{*}{15} & 166331922 & 708503 & 167040425 \\
\hline & 99.58 & 0.42 & 100.00 \\
\hline & 66.25 & 73.92 & 66.28 \\
\hline & 66.00 & 0.28 & 66.28 \\
\hline \multirow[t]{4}{*}{65} & 12485229 & 23683 & 12508912 \\
\hline & 99.81 & 0.19 & 100.00 \\
\hline & 4.97 & 2.47 & 4.96 \\
\hline & 4.95 & 0.01 & 4.96 \\
\hline \multirow[t]{4}{*}{ Total } & 251077412 & 958417 & 252035829 \\
\hline & 99.62 & 0.38 & 100.00 \\
\hline & 100.00 & 100.00 & 100.00 \\
\hline & 99.62 & 0.38 & 100.00 \\
\hline
\end{tabular}




\subsection{Virtue Model People Migration}

To construct the probit model, the authors run 4 times simulation. The first simulation, the authors include all of independent variable. The result shows that variable Edui, NTBi, Uempi, and Empi are not significant at level 5 percent. On the second simulation, the authors eliminate those previous variables and the result show there are one predictor that unlikely provide best estimation for movement to Bali i.e. Poori. Therefore, it is not involved on the next simulation. On third simulation, the rest of right hand side variable all significant. However, the author still need to add previous variable that has been eliminated (Empi). The last simulation provides satisfied estimation and all coefficient significant. Thus, the predicted probability of Bali is as follows, where $\mathrm{F}$ is the cumulative distribution function of the standard normal.

$$
\begin{gathered}
F\left(-1.803495-0.0104938 \text { bjective }_{i}+2.98 e-08 \text { Capita }_{i}-0.2320647 \text { NTT }_{i}+0.0674366 \text { Emp }_{i}\right. \\
\left.-.2078581 \text { Jeek }_{i}\right)
\end{gathered}
$$

A positive coefficient means that an increase in the predictor leads to an increase in the predicted probability of move to Bali. A negative coefficient suggests an increase in the predictor leads to a decrease in the predicted probability of move to Bali. The coefficient of Objective $_{i}$ is -0.0104938 . This means that an increase in Objective decreases the predicted probability of move to Bali. The Capita ${ }_{i}$ has coefficient $2.98 \mathrm{e}-08$. The value implies that an increase in Capita increase the predicted probability of move to Bali. The coefficient of NTT as much as -0.2320647 reflects that an increase in $\mathrm{NTT}_{i}$ decrease the predicted probability of move to Bali.

The coefficient of Empi is -0.0674366 . This indicates an increase in $\mathrm{Emp}_{\mathrm{i}}$ increase the predicted probability of move to Bali. Then, the coefficient of Jseek is -.2078581 . It shows that an increase in Jseek decrease the predicted probability of move to Bali. Finally, the constant term has coefficient -1.803495 . This value means that if all of the predictors are evaluated at zero, the predicted probability of admission is $F(-1.803495)=0.036989356$. So, as expected, the predicted probability of a people with predictors are evaluated at zero has an extremely low predicted probability of move to Bali.

\begin{tabular}{|c|c|c|c|c|}
\hline Bali & Model 1 & Model 2 & Model 3 & Model 4 \\
\hline \multirow[t]{2}{*}{ Objective } & 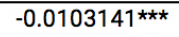 & 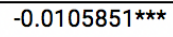 & $-0.0105705^{\star \star \star}$ & 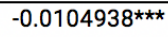 \\
\hline & $(0.0029577)$ & $(0.0027673)$ & $(0.0027668)$ & $(0.0027697)$ \\
\hline \multirow[t]{2}{*}{ Edu } & -0.0023623 & & & \\
\hline & $(0.0018507)$ & & & \\
\hline \multirow[t]{2}{*}{ Capita } & $3.03 \mathrm{E}-08^{\star \star \star}$ & $2.96 \mathrm{E}-08^{\star \star \star}$ & $3.01 \mathrm{E}-08^{\star \star \star \star}$ & $2.98 \mathrm{E}-08^{\star \star \star \star ~}$ \\
\hline & $(4.14 \mathrm{E}-09)$ & $(3.91 \mathrm{E}-09)$ & (3.89E-09) & (3.90E-09) \\
\hline \multirow[t]{2}{*}{ Poor } & -0.1774322 & -0.1168221 & & \\
\hline & $(0.075672)$ & $(0.0654832)$ & & \\
\hline \multirow[t]{2}{*}{ Ntb } & 0.1001672 & & & \\
\hline & $(0.0564819)$ & & & \\
\hline \multirow[t]{2}{*}{$\mathrm{Ntt}$} & 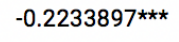 & 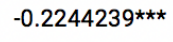 & $-0.2253261^{\star \star \star}$ & $-0.2320647^{\star \star \star *}$ \\
\hline & $(0.0588512)$ & $(0.0559962)$ & $(0.0560033)$ & $(0.0560163)$ \\
\hline \multirow[t]{2}{*}{ Uemp } & -0.0254195 & & & \\
\hline & $(0.0314481)$ & & & \\
\hline \multirow[t]{2}{*}{ Emp } & 0.0511087 & & & $0.0674366^{\star \star \star}$ \\
\hline & $(0.0304696)$ & & & $(0.0146462)$ \\
\hline \multirow[t]{2}{*}{ Jseek } & $-0.1935741^{\star \star \star}$ & $-0.2042322^{\star \star \star}$ & $-0.2047523^{\star \star \star}$ & $-0.2078581^{\star \star \star}$ \\
\hline & $(0.0527202)$ & $(0.0524249)$ & $(0.052406)$ & 0.05239 \\
\hline \multirow[t]{2}{*}{ _cons } & $-1.77606^{\star \star \star}$ & 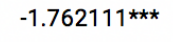 & 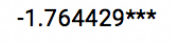 & $-1.803495^{\star \star \star}$ \\
\hline & $(0.0325382)$ & $(0.0173492)$ & $(0.0172981)$ & $(0.0193407)$ \\
\hline
\end{tabular}

Table 7. Probit regression for people movement 


\begin{tabular}{ccccc}
\hline Number of obs & 93,913 & 105,972 & 105,972 & 105,972 \\
LR chi2(5) & 126.58 & 112.62 & 109.27 & 130.58 \\
Prob > chi2 & 0.000 & 0.000 & 0.000 & 0.000 \\
Pseudo R2 & 0.0043 & 0.0034 & 0.0033 & 0.0039 \\
\hline
\end{tabular}

The model shows the most influential factors of people go to Bali are the Objective, Capita, NTT, Emp, and Jseek variables. Based on the Appendix G, the reason people to go to Bali is visiting friends or family (57\%), vacationing or recreation $(22.68 \%)$, and purpose due to work (6.64\%). The Capita variable does not show that people go to Bali because of the motivation to get a job or increase income. The tendency is visible; people will go to Bali because they have enough income. With large earning, it can be assumed they will be able to buy tickets and accommodation. However, this does require further research.

NTT variables have a negative sign, in relation to displacement, NTT people do not have a strong motivation to move to Bali. Then, through Emp variable, it describes that people who already have a job will have a strong motivation to go to Bali. The motivation of the person probably because they want to increase their income based on their skill. In addition, the driving factor because it has sufficient wage or earning. This condition may be related to insight in the Capita variable. These results could provide for further research. However, this does not apply to people who looking for work. Bali not yet be a magnet for people looking for work there. This is shown from the Jseek variable coefficients.

\section{Conclusion}

As magnitude of tourism economy in Indonesia, Bali has big impact not only on National tourism economy but also tourism activity in neighbor region. Analysis of tourism flow spillover, as stated in OLS model; the variables associated with infrastructure, investment, and tourism attraction has no significant effect. It is probably that the model tested in previous research only applied for continent countries. The flow of tourism in archipelago countries such as Indonesia needs to be adjusted. Role of sea transportation or tour and travel services contribution will show significant result in spillover effect in Bali tourism.

Stepwise regression indicates air transportation plays a very important role in the inflow of tourism. Policy implication for that issue, central and regional governments need to strengthen cooperation with the private sector in order to build and improve accessibility and domestic connectivity. It can be applied by connecting growth centers and remote areas through development and development of Provincial and remote Provincial Capital Airports. Also, improve air transportation services in accordance with Minimum Service Standards (MSS).

Obviously, people in NTB and NTT prefer to stay in their area. Thus, develop West and East Nusa Tenggara region as "new" tourism region will be the best way in the future. To achieve that target, government with local business participation should accelerate new tourism areas development such as Mandalika (NTB) and Labuan Bajo (NTT). Diversity and competitiveness tourism products/services are keys of success. This new hub will certainly be able to develop agglomeration in NTB and NTT areas. As a result, it will enlarge the spill over the tourism economy in Bali-Nusa Tenggara region.

\subsection{Extension}

Both tourism flow and motivation of migration research, researchers need to add time series data. It is necessary to observe changes in effects related to economic crisis and treatment of tourism sector. In addition, in order to see widely agglomeration can also be added information from other regions, so it can be seen how the inter-region linkages. Moreover, it is important to identify tax policy on tourism. Policy makers need to know how the mechanism of deployment and utilization of the tax thus the physical impact of tourism can observe. 


\section{References}

Badan Pusat Statistik Propinsi Bali. (2012). Bali Province in Figure 2012 (Publication Number:51000.1601). Retrieved from Badan Pusat Statistik Propinsi Bali website :https://bali.bps.go.id/index.php/publikasi/505855

Badan Pusat Statistik Propinsi Nusa Tenggara Barat. (2012). Nusa Tenggara Barat Province in Figure 2012 (Publication Number:52560.1601). Retrieved from Badan Pusat Statistik Propinsi Nusa Tenggara Barat website:http://ntb.bps.go.id/index.php/publikasi index?Publikasi\%5BtahunJudul\%5D=\&Publikasi\%5BkataKunci\%5D=dalam+angka\& yt0=Tampilkan

Badan Pusat Statistik Propinsi Nusa Tenggara Timur. (2012). Nusa Tenggara Timur Province in Figure 2012 (Publication Number:53560.1618). Retrieved from Badan Pusat Statistik Propinsi Nusa Tenggara Timur website:http://ntb.bps.go.id/index.php publikasi/index?Publikasi\%5BtahunJudul\%5D=\&Publikasi\%5BkataKunci\%5D= dalam+angka\&yt0=Tampilkan

Carrascal Incera, A., Fernández Fernández, M., \& Pereira López, X. (2015). Spillover Effects of Tourism Consumption Between Galicia and the Rest of Spain. International Journal Of Tourism Research, 17(2), 185-195. doi:10.1002/jtr.1978

Capello, R. (2016). Regional Economics (2nd ed). New York, NY :Routledge.

OECD. (2016). An OECD Review of Statistical Initiatives Measuring Tourism at Sub National Level (OECD Tourism Papers, 2016/01). OECD Publishing: Paris. http:/ dx.doi.org/10.1787/5jln3b32hq7h-en

Palamalai, S., \& Kalaivani, M. (2016). Tourism Expansion and Economic Growth in Asia-Pacific Nations: A Panel Causality Approach. IUP Journal Of Applied Economics, 15(2), 53 82.

Smith, S. L. J. 1983. Recreation Geography. Longman: New York.

Yang, Y., \& Wong, K. F. (2012). A Spatial Econometric Approach to Model Spillover Effects in Tourism Flows. Journal Of Travel Research, 51(6), 768-778.

doi:10.1177/0047287512437855 